\title{
Aplikasi Peminjaman dan Pengembalian Tools di Perusahaan PT. Esco Bintan Indonesia Berbasis $W e b$
}

\author{
Liza Safitri ${ }^{1}$, Muhammad Saleh H. Umar ${ }^{2}$, M. Aldi Mahendra ${ }^{3}$ \\ ${ }^{1,2,3}$ Jurusan Sistem Informasi STT Indonesia Tanjungpinang \\ Jln. Pompa Air No. 28 Tanjungpinang Kepulauan Riau Indonesia \\ ${ }^{1}$ savetree3300@gmail.com \\ 22saleh_bis@yahoo.com \\ 3aldimahendra29@gmail.com
}

\begin{abstract}
Intisari - Pada tahun 1978,Esco didirikan di singapura untuk menyediakan solusi udara bersih untuk industri berteknologi tinggi dan industri ilmu pengetahuan website escoindonesia.com .Dari sana, Esco berkomitmen untuk memberikan solusi terbaik dalam kemampuan teknologi untuk menciptakan dunia yang lebih bersih, sehat, dan aman. Dalam penelitian ini yang dijadikan sebagai objek penelitian yaitu dalam sistem peminjaman dan pengembalian tools. Dalam operasional kegiaatanya masih menggunakan sistem manual dan konvesional, belum di dukung oleh sebuah sistem yang terintegrasi. Dari hasil pengamatan dan penelitian, penulis akhirnya membangun sebuah Sistem Informasi sebagai solusinya. Sistem Informasi dirancang dan dibangun dengan platform berbasis web dengan menggunakan Notepad++ sebagai editor pemrogramannya, MYSQL front sebagai editor data base, XAMPP sebagai server data base serta $P D F$ sebagai media penampil laporan. Menerapkan metode Squence Diagram dalam pengembangan perangkat lunaknya. Sistem Informasi baru ini diharapkan dapat membantu dalam aktivitas perusahaan, seperti dalam pembuatan form peminjaman, form pengembalian dan laporan peminjaman dan pengembalian, dll. Dengan penerapan Sistem Informasi ini diharapkan dapat meningkatkan efisiensi, efektivitas dan kinerja perusahaan Pt Esco Bintan. Setelah adanya Sistem Informasi ini perusahaan dapat mengopersikan sistem ini lebih cepat dan mudah tidak memerlukan waktu yang sangat lama dalam mengoperasikan pekerjaan. Dan perusahaan sangat mudah untuk mencari document yang dibutuhkan dan penyimpanannya sangat safety tidak mudah hilang.
\end{abstract}

Kata kunci-Form peminjaman, Form pengembalian, Laporan, Web Design

\begin{abstract}
In 1978, Esco was established in Singapore to provide clean air solutions for the high-tech and science industry website escoindonesia.com. From there, Esco is committed to providing the best solutions in technological capabilities to create a cleaner, healthier and safer world. In this study, which is used as an object of research that is in the system of borrowing and returning tools. In operational activities it still uses a manual and conventional system, unsupported by an integrated system. From the observations and research, the author finally built an Information System as solution. The information system is designed and built with a webbased platform using Notepad ++ as its programming editor, MYSQL front as a data base editor, XAMPP as a database server and PDF as a report viewer media. Apply the Squence Diagram method in software development. This new information system is expected to be able to assist in the company's activities, such as in making loan forms, return forms and loan and repayment reports, etc. The application of this Information System is expected to improve the efficiency, effectiveness and performance of the company PT Esco Bintan. After the existence of this Information System the company can operate this system more quickly and easily without requiring a very long time to operate the work. And the company is very easy to find the required documents and storage is very safe not easily lost
\end{abstract}

Keywords— Loan Form, Return Form, Report, Web Design

\section{Pendahuluan}

Perkembangan dalam bidang komputer pada saat ini telah membuka peluang seluas-luasnya kepada para pakar dan para pengambil keputusan,baik yang bergerak dibidang, pemerintahan, ekonomi dan sebagainya untuk menyelesaikan semua permasalahannya dengan menggunakan komputer. Sebelum datang era komputerisasi ini kebanyakan dari perusahaan menyelesaikan pekerjaannya secara manual. Tetapi saat ini perusahaan dapat menggunakan komputer dalam mengerjakan berbagai tugasnya dengan cepat dan tepat. Hal ini dikarenakan didalam komputer tersebut terdapat bermacam-macam aplikasi yang bisa digunakan, sehingga instansi tersebut mendapatkan kemudahan dalam menyelesaikan pekerjaannya.

Sebuah organisasi manajemen bisnis menggantungkan diri pada sistem informasi untuk mempertahankan kemampuan berkompetisi. Informasi pada dasarnya adalah sumberdaya seperti halnya pabrik dan peralatan. Produktivitas, sebagai suatu hal yang penting agar tetap kompetitif, dapat ditingkatkan melalui sistem informasi yang baik.

Pengolahan data dan informasi yang secara cepat, tepat, dan efisien adalah hal penting yang dibutuhkan bagi setiap pelaku bisnis untuk memberikan pelayanan yang maksimal sehingga mamapu memberikan kepuasan kepada pelanggan. Pelanggan adalah satu-satunya alas an eksistensi bagi pelaku bisnis. PT Esco Bintan merupakan salah satu perusahaan 
yang ada di Kabupaten Sri Kuala Lobam. Perusahaan ini memiliki banyak departement di dalam satu gendung. Ketika penulis mengamati di departement tempat penulis bekerja, penulis melihat bahwa ketika karyawan ingin meminjam dan mengembalikan tools untuk peralatan kerja karyawan harus menulis secara manual yaitu dengan cara menulis, dan data yang telah di tulis sering hilang karena penyimpanannya tidak safety. Dengan adanya komputer sebagai alat mempermudah pekerjaan, maka dalam suatu bidang perusahaan ataupun intansi dapat dikomputerisasikan, dalam hal ini bidang-bidang yang dianggap penting dan utama karena hal ini dapat mendukung keberhasilan suatu perusahaan atau instansi dalam mencapai tujuan. Dalam kajian ini penulis ingin memberikan suatu solusi dengan merancang dan mengaplikasikan suatu alur kerja sistem peminjaman berdasarkan sistem pinjaman manual yang ada pada PT Esco Bintan yang masih kurang efektif dan efisien dalam peminjaman, pengembalian, pembuatan sistem ini akan menggunakan aplikasi peminjaman yang terkomputerisasi dengan sebaik mungkin.

Untuk memenuhi skripsi ini dengan Program Sistem Informasi, maka penulis ingin mencoba merancang suatu aplikasi berbasis web dengan maksud dapat membantu dalam hal menangani permasalahan - permasalahan pengolahan data peminjaman dan pengembalian serta membantu pimpinan dalam proses pengambilan keputusan berdasarkan laporan yang disajikan sistem.

\section{Metodologi Penelitian}

Metodologi penelitian merupakan suatu teknik atau untuk mengumpulkan data yang nantinya akan dipelajari dan akhirnya sebagai bahan untuk di analisa.

A. Metode Pengumpulan Data

1) Observasi

Melakukan observasi/analisa tempat sebelum pengumpulan data dengan mengadakan pengenalan terhadap skripsi.

2) Wawancara

Melakukan wawancara secara langsung dengan karyawan yang berada dalam sistem aplikasi untuk pembuatan skripsi.

\section{3) Studi Pustaka}

Melakukan pengumpulan data secara tidak langsung dengan melakukan penambahaan ilmu yang ada di perpustaka, yaitu dengan mengumpulkan informasi-informasi dan teoriteori yang berhubungan dengan penulisan laporan skripsi ini.

\section{B. Metode Pengembangan Perangkat Lunak}

Metode pengembangan perangkat lunak yang digunakan dalam membangun sistem informasi ini menggunakan model Prototyping yang menyarankan pengembangan perangkat lunak secara sistematik dan berurutan yang dimulai dari tingkatan sistem tertinggi dan berlanjut ke tahap analisis, desain, pengkodean, pengujian dan pemeliharaan. Kelebihan dari metode ini adalah terstruktur, dinamis, dan sequential.

\section{HASIL DAN PEMBAHASAN}

\section{A. Analisa Sistem}

Analisis sistem adalah teknik pemecahan masalah yang menguraikan bagian-bagian komponen dengan mempelajasi seberapa bagus bagian - bagian komponen tersebut bekerja dan berinteraksi untuk mencapai tujuan mereka.
1. Prosedur peminjaman tools yang sedang berjalan

a. Karyawan sebelum meminjam tools harus mengisi form peminjaman.

b. Setelah karyawanmmengisi form peminjaman leader akan mengecek data yang telah diisi karyawan PT. ESCO Bintan Indonesia.

c. Selanjutnya karyawan akan mengambil tools yang mau dipinjam.

d. Leader akan membuat laporan peminjaman untuk supervisor dan arsip.

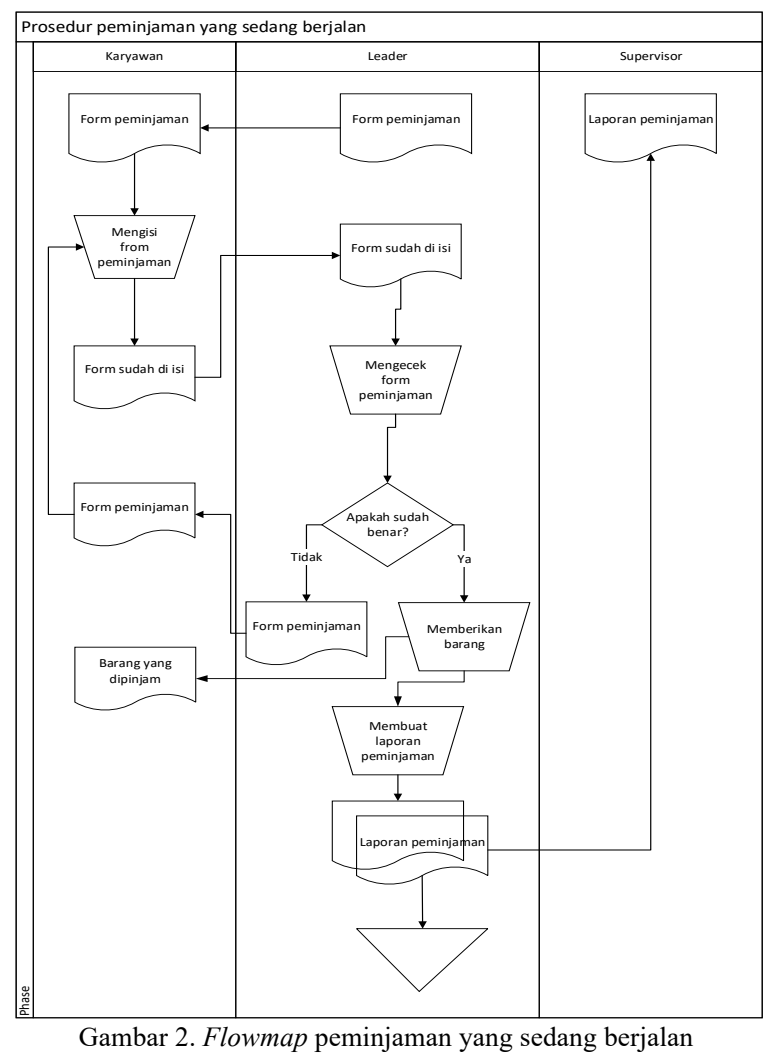

2. Prosedur pengembalian tools yang sedang berjalan

a. Karyawan sebelum mengembalikan tools harus mengisi form pengembalian.

b. Setelah karyawan mengisi form pengembalian leader akan mengecek data yang telah di isi karyawan PT. ESCO Bintan Indonesia.

c. Selanjutnya karyawan akan meletakkan tools yang mau di kembalikan. Leader akan membuat laporan pengembalian untuk supervisor dan arsip. 


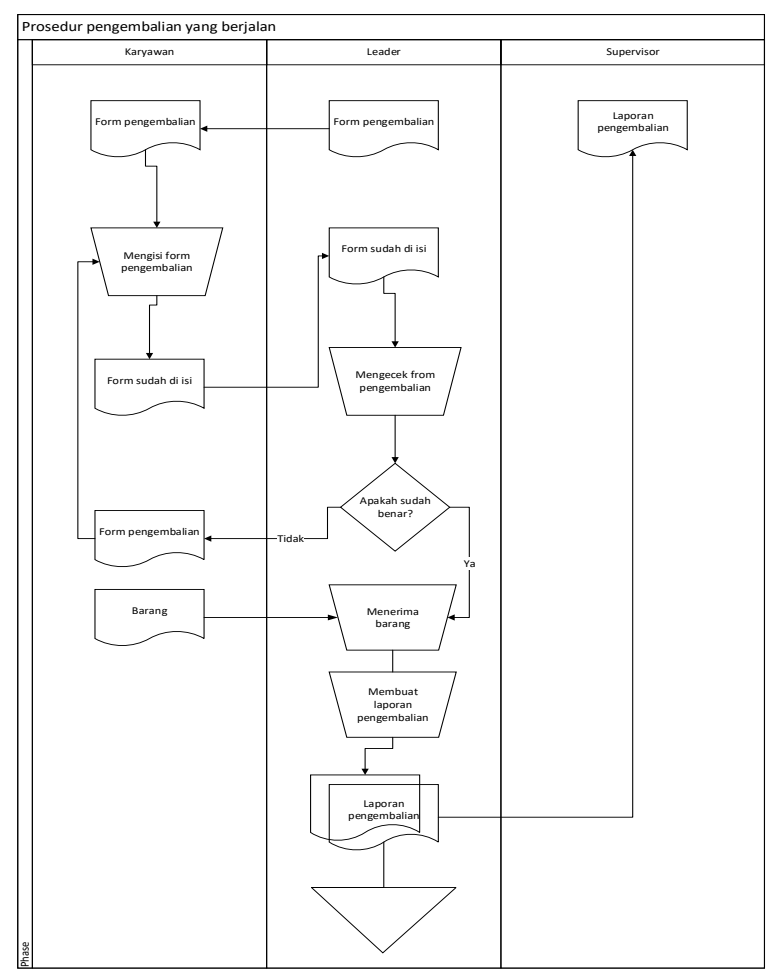

Gambar 3. Flowmap pengembalian yang sedang berjalan.

\section{B. Perancangan Sistem}

Perancangan sistem dapat didefinisikan sebagai penggambaran, perencanaan dan pembuatan sketsa atau pengaturan dari beberapa elemen yang terpisah ke dalam satu kesatuan yang utuh dan berfungsi.

1) Prosedur peminjaman tools yang diusulkan

a. Karyawan mengisi form tools peminjaman.

b. Leader akan melakukan pengecekan form peminjaman tools yang telah di isi oleh karyawan.

c. Leader akan menginput data ke dalam database.

d. Karyawan akan menggambil tools yang ingin di pinjam.

e. Leader akan membuat laporan yang akan di berikan kepada manager dan arsip.

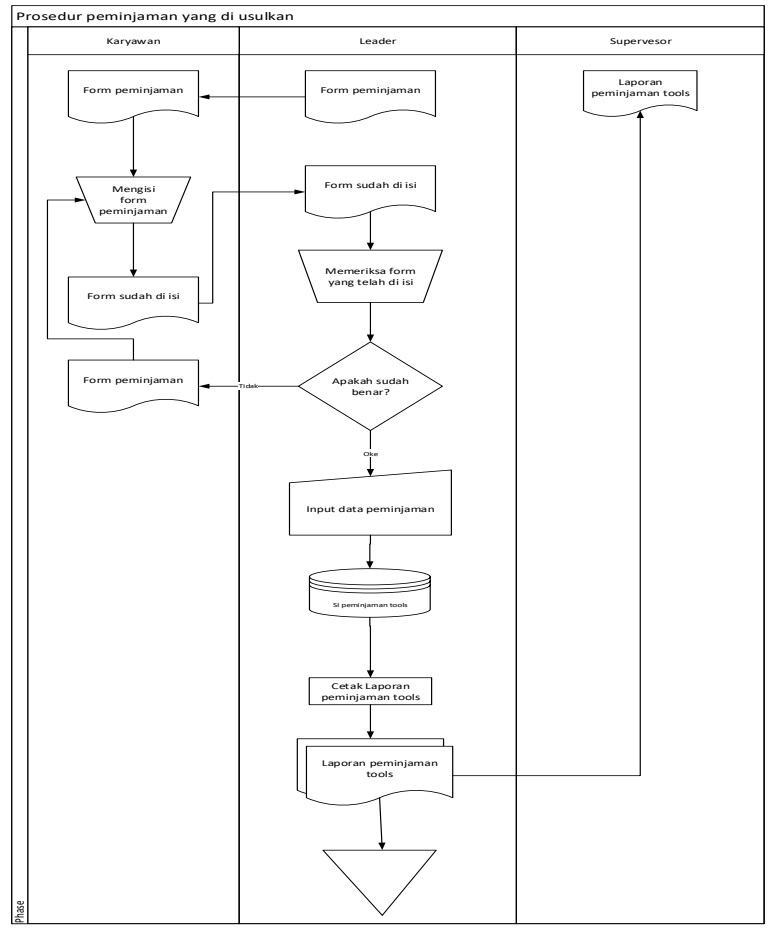

yang diusulkan

Gambar 4. Flowmap peminjaman tools

2) Prosedur pengembalian tools yang diusulkan

a. Karyawan akan mengisi form pengembalian tools.

b. Leader akan menginput form pengembalian tools di database.

c. Leader akan membuat laporan pengembalian tools yang akan di serahkan kepada manager dan arsip.

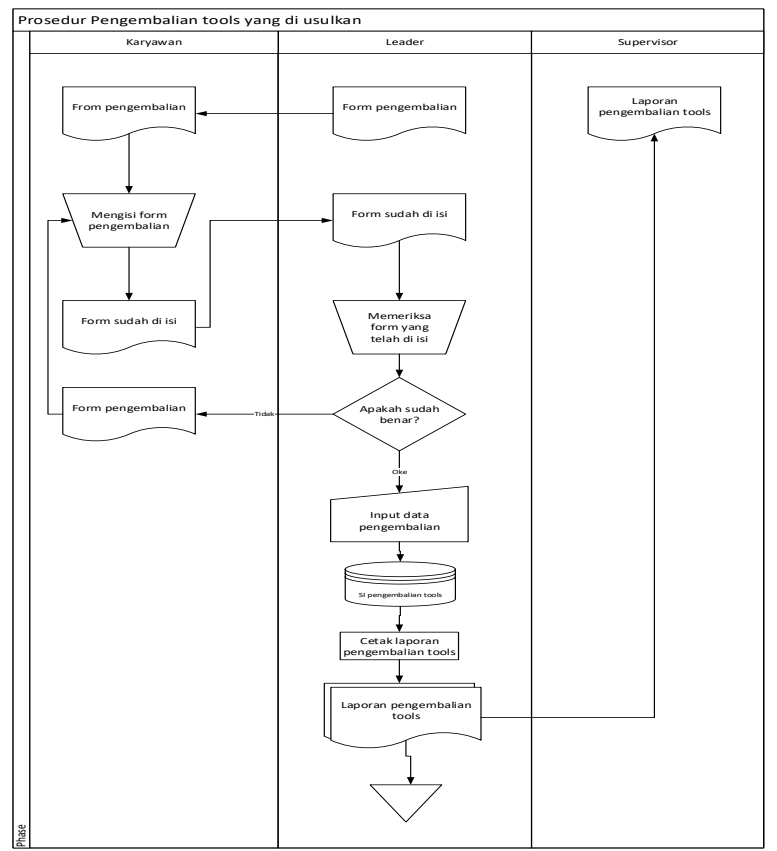

Gambar 5. Flowmap pengembalian tools yang diusulkan

3) Diagram konteks 


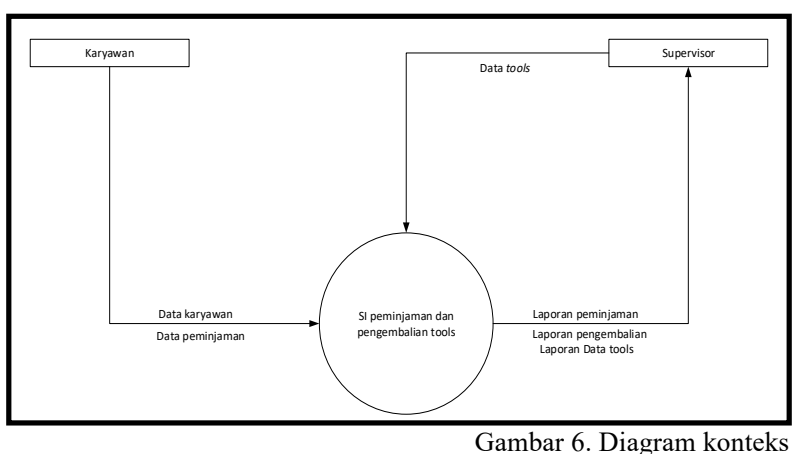

Penjelasan :

Diagram konteks adalah diagram yang menggambarkan hubungan antara entitas eksternal dengan sistem. Dimana data yang diinputkan oleh bagian entitas eksternal akan diproses didalam sistem dan akan menghasilkan laporan yang diinginkan oleh entitas eksternal tersebut.

\section{4) Data flow diagram}

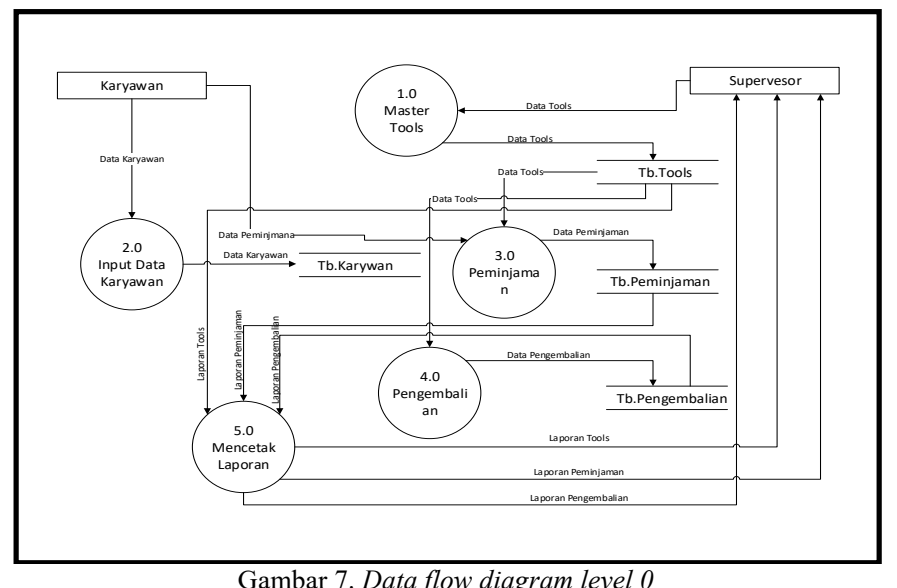

Penjelasan :

DFD sering digunakan untuk menggambarkan suatu sistem yang telah ada atau sistem yang baru yang akan dikembangkan secara logika dan menjelaskan arus data dari mulai pemasukan sampai dengan keluaran data tingkatan diagram arus data mulai dari diagram konteks yang menjelaskan secara umum suatu system atau batasan system dari level 0. Gambaran ini tidak tergantung pada perangkat keras, perangkat lunak, struktur data atau organisasi file.

\section{5) Entity relationship diagram}

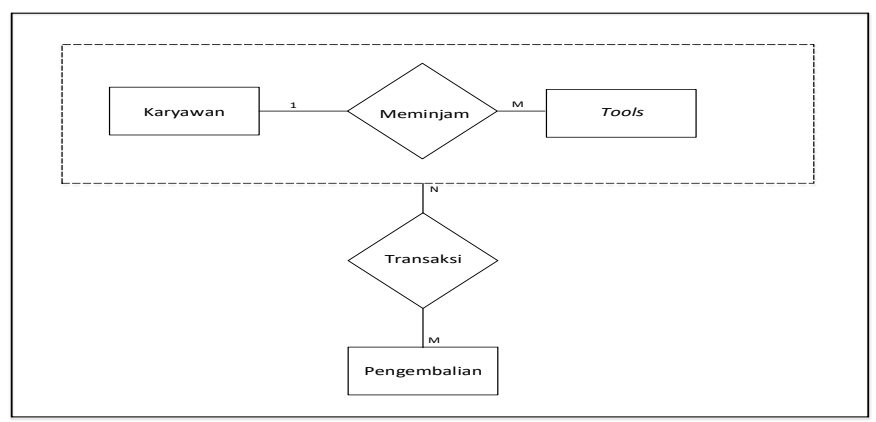

Gambar 8. Entity Relationship Diagram
Penjelasan :

Tujuan dari perancangan struktur file ini yaitu untuk menentukan nama field, tipe field, lebar field, dan key dari field tersebut yang ada pada setiap tabel. Struktur file yang akan digunakan dalam perancangan sistem ini akan menentukan struktur fisik dari Sistem Informasi Peminjaman dan Pengembalian Tools Berbasis Web Pada PT. ESCO Bintan Indonesia yang menunjukkan struktur dari elemenelemen yang menyatakan panjang data dan tipe datanya. Pengembangan struktur tabel yang akan diuraikan adalah sebagai berikut:

\section{6) Struktur menu}

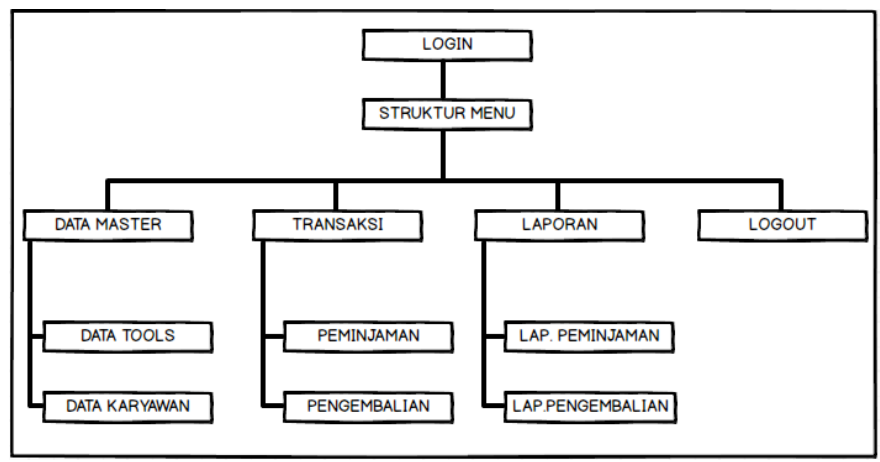

Gambar 9. Struktur menu

\section{KESIMPULAN}

Berdasarkan hasil implementasi Sistem Informasi Peminjaman dan Pengembalian Tools Pada Perusahaan Pt Esco Bintan Indonesia yang telah selesai dibangun, maka dapat ditarik kesimpulan sebagai berikut :

1. Sistem Informasi Peminjaman dan Pengembalian Tools Pada Perusahaan Pt Esco Bintan Indonesia sudah menggunakan tempat penyimpanan data berupa database yang terstruktur dan tidak menghabiskan ruang penyimpanan, sehinga kesulitan yang yang terjadi pada sistem lama seperti kesalahan pencarian dokumen, data tools dan lain - lain sudah dapat diatasi.

2. Dengan diterapkannya sistem ini, maka proses pembuatan form peminjaman, faktur pengembalian, data tools sudah terkomputerisasi sehingga dapat menghemat waktu, data lebih akurat, efisien dan data dapat terhubung dengan data pada proses yang lain.

3. Dengan adanya sistem ini, maka diharapkan akan mempermudah dan mempercepat dalam proses pembuatan laporan, seperi laporan peminjaman tools, laporan pengembalian tools.

4. Data rekapitulasi tools yang belum di kembalikan dan sudah di kembalikan dapat langsung diketahui melalui sistem ini, sehingga mempermudah dalam menentukan skala prioritas peminjaman dan pengembalian tools tsb. 


\section{REFERENSI}

[1] Awaludin, Rahmat Menyelami Framework Laravel, Bandung, 2016.

[2] Dominikus Juju \& Matamaya Studio, Seri Penuntun Praktis Join Multiply, PT. Elex Media Komputindo, Jakarta, 2016.

[3] Hendradjaya, Bayu Konsep Dasar Pengujian Perangkat Lunak, Penerbit ITB, Bandung, 2017.

[4] Kristanto, Andri, Perancangan Sistem Informasi dan Aplikasinya Edisi Revisi, PENERBIT GAVA MEDIA, Yogyakarta, 2018.

[5] Liana, Linda, Pengujian Perangkat Lunak, Universitas Mercu Buana, Jakarta, 2016.

[6] Murdick Robert G, Sistem Informasi untuk manajemen Modern. PT. Erlangga, Jakarta, 2017.

[7] Muslihudin, Muhammad, Oktafianto, Analisis dan Perancangan Sistem Informasi Menggunakan Model Terstruktur dan UML, Andi Offset, Yogyakarta, 2016.
[8] Nugroho, Bunafit. PHP \& MySQL dengan Editor Dreamweaver MX, Yogyakarta. 2015.

[9] Riyanto, Slamet, Membuat Web Portal Multi Bahasa Jomla, PT. Elex Media Komputindo, Jakarta, 2016.

[10] Rusdiana dan Moch. Irfan, Sistem Informasi Manajemen, Pustaka Setia, Bandung, 2018.

[11] Sitorus, Lamhot, Algoritma dan Pemograman, Penerbit ANDI, Yogyakarta, 2015.

[12] Susanto, Azhar. Sistem Informasi Akuntansi, Lingga Jaya, Bandung, 2016.

[13] Solichin, Achmad, MySQL 5 Dari pemula hingga mahir, PT. Elex Media Komputindo, Jakarta, 2017.

[14] Supardi, Yuniar Mudah dan Cepat Membuat Skripsi dengan VB 2017, PT. Elex Media Komputindo, Jakarta, 2015. 